\title{
HEPATOLO GY
}

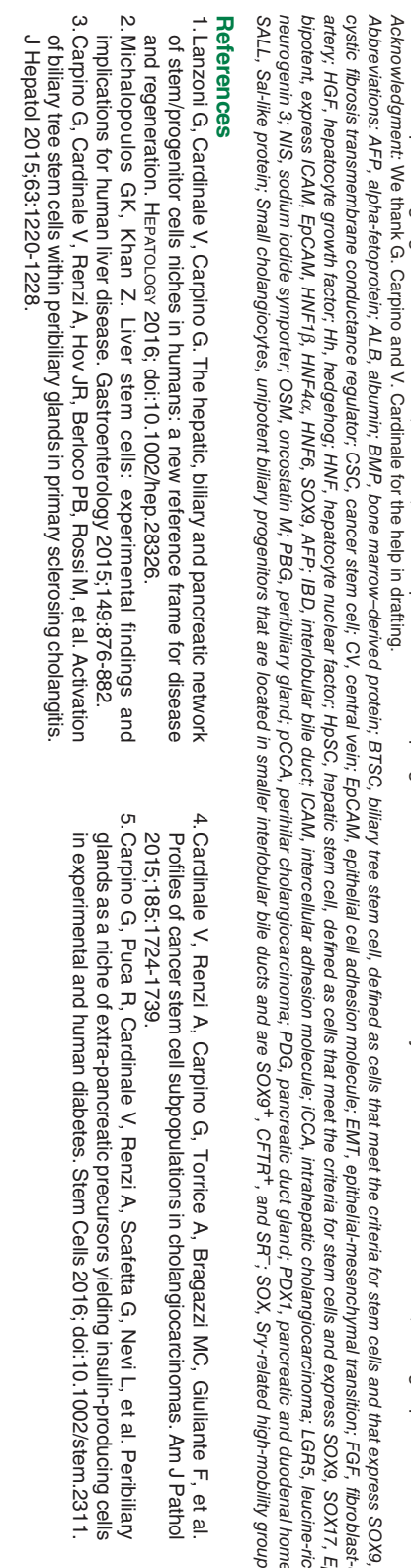

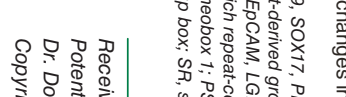

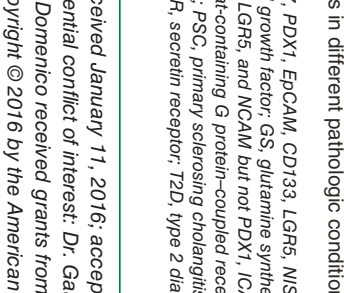

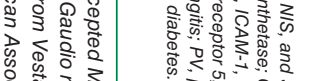

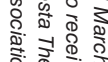

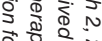

की

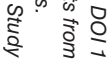

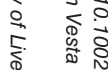

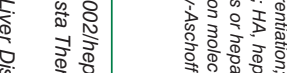

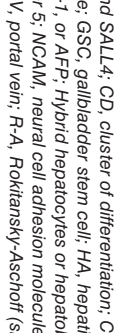

Radial axis of maturation 1

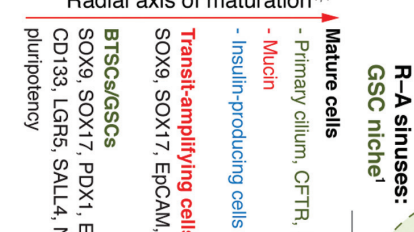
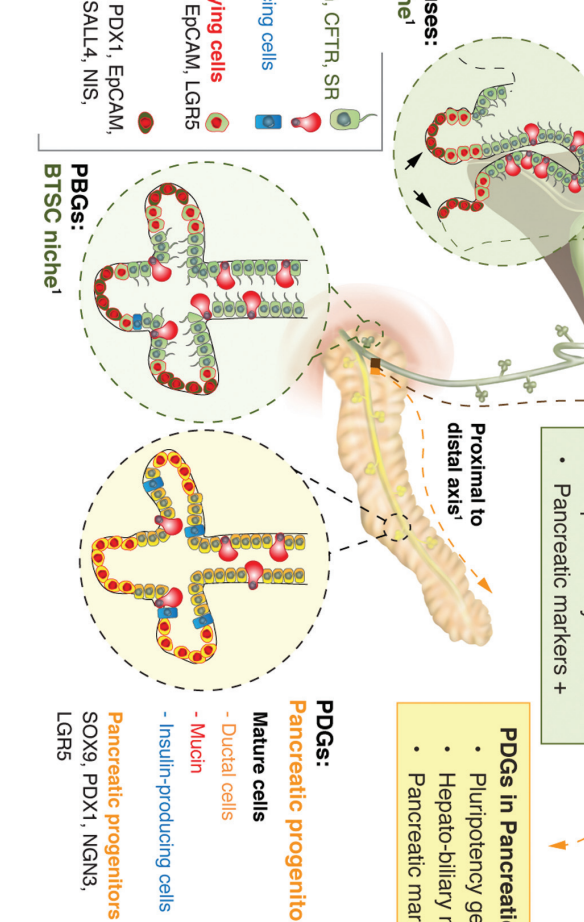

Radial axis of maturation ${ }^{5}$

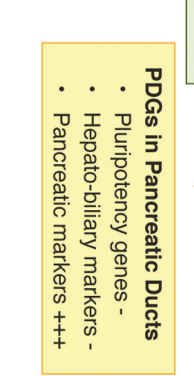

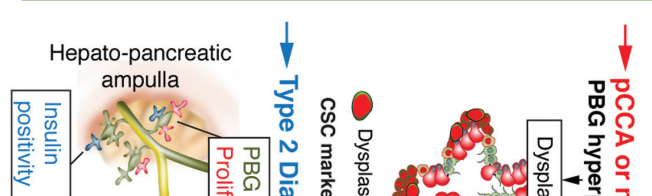

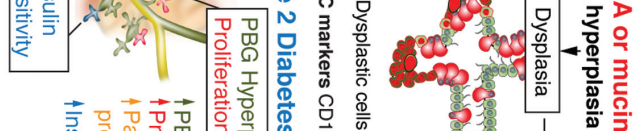

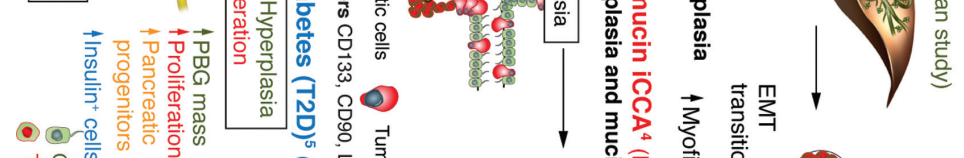

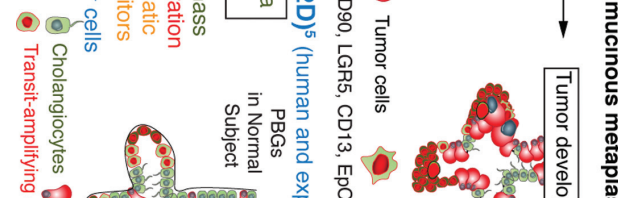

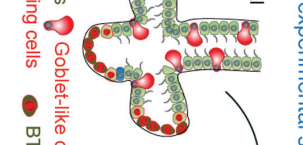

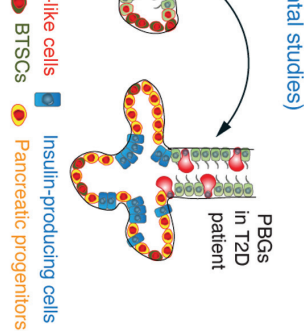
II

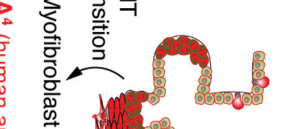

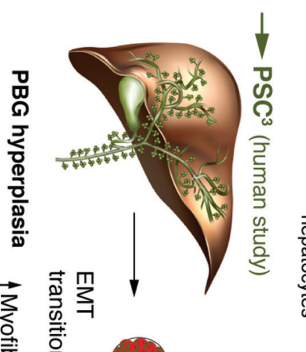<smiles>C1=CC2C=CC(C1)C2</smiles>

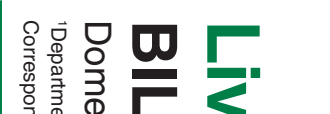

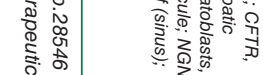

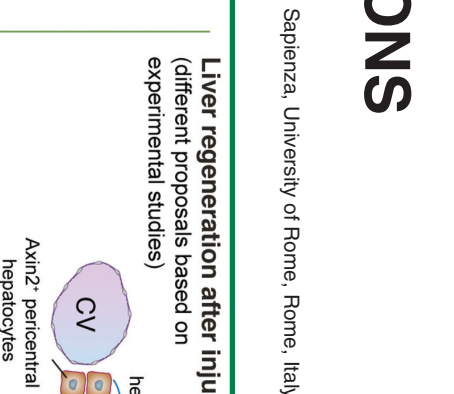

